\title{
The Influence of Loyalty, Competence, and Working Environment on the Administrative Staff Performance at Manado State University, Indonesia
}

\author{
Yance Tawas \\ Faculty of Economics, Manado State University, Indonesia
}

\begin{abstract}
The purpose of this study is to investigate the influence of loyalty, competence and working environment on the administrative staff performance at Manado State University in simultaneous and partial way. This study used explanatory study with quantitative approach. Data collected through questionnaires. Purposive sampling was used with 120 respondents as research sample from administrative staff who held bachelor degree background. The statistical data was analysed using multiple linear regression employing SPSS version 16. The result of partial test showed that the variable of loyalty, competence, and working environment had the significant influence and positive contribution on the administrative staff performance at Manado state university. The results of this research are expected to give the idea contribution to the staff at Manado State University in order to have concern on research variables, so the performance and administration service could be improved. Moreover, this study could be the reference for bachelor degree or postgraduate students who are interested in this topic of research. Research sample in this study is still limited with only multiple regression analysis technique, therefore it will be the opportunity for further studies to conduct this kind of research and use the various sample and comprehensive analysis technique.
\end{abstract}

Keywords: Loyalty, Competence, Working Environment, Staff Performance

\section{Introduction}

The picture of Indonesian civil servants is closely related to the poor performance, inappropriate welfare, and low ratio of distribution. The phenomenon shows the poor condition such as incompetence to do their tasks, inconsistency in disciplinary, lack of objectivity in performance measurement by the leaders to their staff, lack of loyalty from staff to their organisation, and inadequate working environment. As a public servant, the government employee has duty and responsibility to conduct service program in professional, truthful, equal, optimal, effective and efficient way. However, in the most government agencies those characteristics are not implemented as expected. The government has attempted to compensate through performance incentive payment and other allowances but the poor condition as mentioned above still occur in government agencies. The staff who has no competence, commitment, and good loyalty are the most likely to create slow service, poor performance, minimum working effort, inefficiency and unable to meet the determined operational procedure.

The development of science and information technology has created easier way and alternative solution to performance problem. Some studies in staff performance reveal that there are several dominant factors which influence staff performance such as individual factor: gender, health, experience; psychological characteristics: motivation, personality, goals orientation, locus of control; situational factor: leadership, work achievement, task complexity, social relationship, organisational culture; and loyalty factor: working environment and competence (Sonia, 2014; Sari 2009; Spencer and Spencer, 1993, Palan, 2007; Rahmawati and Nela, 2014 and Untari, 2014).

According to Simamora (1997), Gibson (1996) and As'ad (2001), the influence factors for performance are classified into individual, psychological and organisational factor. Individual factor which consists of ability, skill, background and demography become the main factor that influence behaviour and performance of individual/staff. Psychology factor consists of perception, attitude, personality, learning, motivation and work satisfaction. Organisational factor consists of resources, leadership, rewards, structure and work design, evaluation system and career. Mangkunegara (2005) states that performance is the work result and quantity that achieved by a staff in performing tasks based on responsibility that given to him/her.

This research explores the items related to staff performance such as competence factor, working environment and loyalty. Spencer and spencer (1993) and Palan (2007) confirm that competence may be created through knowledge and skill, self-concept and value, personal characteristic, and motives that possess by a person to improve his/her best performance in working place. Sedarmayanti (2007) also states that competence has various factors such as technical and non-technical, personality and behaviour, soft and hard skill, which used as value aspect in organisation. Working environment factor is one of the supporting factors to elevate staff performance, Mangkunegara (2005) argue that working environment is related to clear job description, challenging work target, effective communication pattern, work climate and adequate working facilities. 
The Influence of Loyalty, Competence, and Working Environment on the Administrative Staff ..

Furthermore, Tyssen (2003) assert that the influence factors of working environment may consist of working facilities, salary and allowance and working relationship. In related work, Saydam (2000) claims that in terms of working loyalty factor of staff, loyalty can be related to submission and obedience, responsibility, dedication and honesty.

Manado state university is the public institution under the Ministry of Research Technology and Higher Education. This Institution has the task and responsibility to undertake the government program in creating professionals and academics. It is expected to present the service according to professional standard and public expectation. However, there is still a big gap between reality and expectation. The observation results revealed that administrative staff performance have the tendency of incompetence to do their work, disobedient in regulations, lack of conducive relationship between leaders and subordinates and inadequate working environment. The interview results to staff show the reasons which influence those conditions such as, the discrepancy of their job position and background skill, lack of good communication between leaders and subordinates, unused job facilities, uncomfortable environment and also the condition of no punishment to disobedient staff brings envious feelings to the others. Those considerations drive this research to focus on staff performance and to set loyalty, competence and working environment as the influence factors. The purpose of the study is to identify and clarify the influence of loyalty, competence and working environment in partial and simultaneous way to the administrative staff at Manado state university.

\section{Staff Performance}

\section{Literature Review and Hypothesis}

Mangkunegara (2005) defines performance as the work result and quantity that achieved by a staff in performing the tasks based on responsibility which given to him/her. Sedarmayanti (2010) states that performance indicator is something that can be measured and counted and used as a platform to value the level of performance in planning stage, implementation and after activities. Performance indicator also can be used to convince that organisational performance/working unit related to show the improvement, in order to achieve determined objectives and goals. Performance consists of quality of work, promptness, initiative, capability and communication (Mitcell, 1978 in Sedarmayanti (2007).

\section{Loyalty}

Loyalty is a general character of a human being when the members of group tend to take side on their own group. The organisational loyalty can cause the members to value their demeanour and to be aware of the consequences of their actions toward the organisation in decision making. Hasibuan (2013) describes loyalty as "a faithfulness of staff to guard and defend the organisation inside or outside their job". Saydam (2000) states several points that cause poor loyalty of staff: (1) Unpleasant working environment, (2) Low compensation (3) Lack of rewards to staff achievements' (4) against staff (5) Low motivation and (6) Poor guarantee of career development. In contrary, the influential factors for loyalty are: obedience, responsibility, dedication and honesty.

\section{Competence}

Spencer and spencer (1993), assert that competence refers to basic characteristics which describes behaviours of personal characteristic, self-concept, values, knowledge or expertise in a person as a superior performer who conveys those characteristics in working place. There are five characteristics that create competence: I). Knowledge: refer to the results of information and learning; 2). Skills: refer to the ability to conduct activities; 3). Self-concept and values: refer to attitude and self-image, such as self-confidence to achieve successful situation; 4). Personal characteristics; refer to physical characteristics and reaction consistency to response the situation or information, such as self-control and ability to survive in under pressure condition; 5). Motives: refer to emotion, desire or motivation and other psychological needs which trigger activities.

\section{Working Environment}

According to Basuki and Susilowati (2005) working environment is everything inside the environment that can influence directly or indirectly to a person or a group of people in undertaking their activities. Working environment is influenced by several factors such as: working facilities, salary and allowance, and work relation.

Hypothesis

Hypothesis in this study are as follows:

1) Partially, it is assumed that loyalty, competence and working environment have influence to administrative staff performance at Manado state university. 2) Simultaneously, it is assumed that loyalty, competence and working environment have influence to administrative staff at Manado State University. 
The Influence of Loyalty, Competence, and Working Environment on the Administrative Staff..

\section{Research Methods}

This study employs explanatory study with quantitative approach and survey method for data collection. Purposive sampling technique was used in research sample. The data collected from administrative staff at Manado state university with bachelor degree as educational background. The number of respondents were 120 from 175 staff who have bachelor degree (according to population and table from Sugiyono, 2007). The distribution percentage can be seen at table below:

\begin{tabular}{|l|l|l|l|}
\hline No & Department & Population & Sample \\
\hline 1 & BAAK & 11 & 8 \\
\hline 2 & BAPKSI & 12 & 8 \\
\hline 3 & BAUK & 48 & 33 \\
\hline 4 & ARSIP (Archive Department) & 2 & 1 \\
\hline 5 & PERPUSTAKAAN (Library) & 16 & 11 \\
\hline 6 & LPM (Community Service Centre) & 7 & 5 \\
\hline 7 & LEMLIT (Research Centre) & 5 & 3 \\
\hline 8 & LP2AI (Instructional Activity Development Centre) & 2 & 1 \\
\hline 9 & PPS (Postgraduate Study Program) & 5 & 3 \\
\hline 10 & PUSKOM (Communication Centre) & 3 & 2 \\
\hline 11 & FATEK (Faculty of Engineering) & 11 & 8 \\
\hline 12 & FBS (Faculty of Language and Arts) & 13 & 9 \\
\hline 13 & FEKON (Faculty of Economics) & 5 & 3 \\
\hline 14 & FIK (Faculty of Sports) & 9 & 6 \\
\hline 15 & FIS (Faculty of Social Science) & 12 & 8 \\
\hline 16 & FMIPA (Faculty of Mathematics and Natural Science) & 14 & 10 \\
\hline & & $\mathbf{1 7 5}$ & $\mathbf{1 2 0}$ \\
\hline
\end{tabular}

Source: UNIMA, 2016

Research was carried out at campus of Manado state university, Tondano in January to March 2016. Research variables are as follows:

1) Independent variables: a) Loyalty (X1) with indicators: obedience, responsibility, dedication and honesty, b) Competence (X2) with indicators: knowledge, skills, self-concept and self-value, personal characteristics and motives, c) Working environment (X3), with indicators: work facilities, salary and allowance and work relation.

2) Dependent variables: staff performance $(Y)$, with indicators: work quality, accuracy, initiative, ability and communication.

The research instrument utilise questionnaire consists of close questions with Likert scale measurement (five alternative answers). Instrument was examined by validity test and reliability (SPSS 16 application program). Validity test used product moment Pearson correlation index with significant level 5\% to critical value. The validity rate is valid if the value $r_{x y} \geq 0,3$ and if the value $r_{x y} \geq 0,3$ the validity rate is invalid. The reliability test in this study used alpha Cronbach, the result test is reliable if the value of $r_{11} \geq 0,6$ and unreliable if the value $r_{11} \leq 0,6$ (Sugiyono, 2007).

Data analysis that employed in this study are as follows:

1) Descriptive analysis: related to the description of respondents' answer from research instrument, mean value and standard deviation.

2) Classic assumption test: normality test, multicollinearity test, autocorrelation test and heteroskidastity test.

3) Multiple linear regression analysis

a. The regression equation model

b. Hypothesis test: Partial test ( $\mathrm{t}$ test) and simultaneous test (F test)

c. Determination coefficient

1. Validity and Reliability Test

\section{Findings}

\begin{tabular}{|c|c|c|c|c|c|c|}
\hline \multirow{2}{*}{$\begin{array}{l}\text { Items/ } \\
\text { Variables }\end{array}$} & \multirow{2}{*}{$\begin{array}{l}\text { Validity } \\
\text { Corrected } \\
\text { Items-Total } \\
\text { Correlation }\end{array}$} & \multicolumn{5}{|c|}{ Reliability } \\
\hline & & Cut Off & Results & $\begin{array}{l}\text { Cronbach's } \\
\text { Alpha }\end{array}$ & $\begin{array}{l}\text { Cut } \\
\text { Off }\end{array}$ & Results \\
\hline $\mathrm{X} 1.1$ & 0.542 & 0.3 & Valid & & & \\
\hline $\mathrm{X} 1.2$ & 0.534 & 0.3 & Valid & & & \\
\hline $\mathrm{X} 1.3$ & 0.691 & 0.3 & Valid & & & \\
\hline $\mathrm{X} 1.4$ & 0.556 & 0.3 & Valid & & & \\
\hline \multicolumn{4}{|c|}{ X1 (Loyalty) } & 0,775 & 0,6 & Reliable \\
\hline $\mathrm{X} 2.1$ & 0.237 & 0.3 & Invalid & & & \\
\hline $\mathrm{X} 2.2$ & 0.475 & 0.3 & Valid & & & \\
\hline $\mathrm{X} 2.3$ & 0.542 & 0.3 & Valid & & & \\
\hline
\end{tabular}


The Influence of Loyalty, Competence, and Working Environment on the Administrative Staff ..

\begin{tabular}{|c|c|c|c|c|c|c|}
\hline $\mathrm{X} 2.4$ & 0.606 & 0.3 & Valid & \multirow[b]{3}{*}{0,706} & \multirow[b]{3}{*}{0,6} & \multirow[b]{3}{*}{ Reliable } \\
\hline $\mathrm{X} 2.5$ & 0.470 & 0.3 & Valid & & & \\
\hline \multicolumn{4}{|c|}{$\mathrm{X} 2$ (Competence) } & & & \\
\hline $\mathrm{X} 3.1$ & 0.568 & 0.3 & Valid & & & \\
\hline $\mathrm{X} 3.2$ & 0.566 & 0.3 & Valid & & & \\
\hline $\mathrm{X} 3.3$ & 0.405 & 0.3 & Valid & & & \\
\hline \multicolumn{4}{|c|}{ X3 (Working Environment) } & 0,683 & 0,6 & Reliable \\
\hline Y1.1 & 0.446 & 0.3 & Valid & & & \\
\hline $\mathrm{Y} 1.2$ & 0.094 & 0.3 & Invalid & & & \\
\hline Y1.3 & 0.454 & 0.3 & Valid & & & \\
\hline Y1.4 & 0.466 & 0.3 & Valid & & & \\
\hline Y1.5 & 0.522 & 0.3 & Valid & & & \\
\hline \multicolumn{4}{|c|}{ Y (Staff Performance) } & 0,624 & 0,6 & Reliable \\
\hline
\end{tabular}

Source: Output SPSS 16, data running in 2016

The results of validity test show that 15 out of 17 items in this study at $r_{x y}>0.3$ (critical value) were from 0.446 to 0.691 , therefore it can be concluded that those 15 items were valid, and two other items, X2.1 and Y1.2 were invalid as the value of $r_{x y}<0.3$ (critical value) were 0.237 and 0.094 . The results of reliability test show that the total variables (loyalty, competence, working environment and staff performance) at $r_{x y}>0.6$ (critical value) were from 0.624 to 0.775 , so those four variables were reliable.

\section{Respondents' Answers Description}

\begin{tabular}{|c|c|c|c|c|c|c|c|c|}
\hline \multicolumn{9}{|c|}{ The Results of Respondents' Answers Description } \\
\hline \multirow{2}{*}{ Likert Scale } & \multicolumn{2}{|c|}{$\mathrm{X} 1$} & \multicolumn{2}{|l|}{$\mathrm{X} 2$} & \multicolumn{2}{|l|}{$\mathrm{X} 3$} & \multicolumn{2}{|l|}{$\mathrm{Y}$} \\
\hline & $\mathrm{F}$ & $\%$ & $\mathrm{~F}$ & $\%$ & $\mathrm{~F}$ & $\%$ & $\mathrm{~F}$ & $\%$ \\
\hline Totally Disagree & 5 & 1.04 & 3 & 0.50 & 9 & 2.50 & 7 & 1.17 \\
\hline Disagree & 41 & 8.54 & 33 & 5.50 & 42 & 11.67 & 57 & 9.50 \\
\hline $\mathrm{RR} / \mathrm{N}$ & 150 & 31.25 & 154 & 25.67 & 126 & 35.00 & 161 & 26.83 \\
\hline Agree & 225 & 46.88 & 315 & 52.50 & 151 & 41.94 & 301 & 50.17 \\
\hline \multirow[t]{2}{*}{ Totally Agree } & 59 & 12.29 & 95 & 15.83 & 32 & 8.89 & 74 & 12.33 \\
\hline & & 100 & & 100 & & 100 & & 100 \\
\hline Mean & \multicolumn{2}{|c|}{14.4333} & \multicolumn{2}{|c|}{18.8833} & \multicolumn{2}{|c|}{10.2917} & \multicolumn{2}{|c|}{18.1500} \\
\hline Std. Deviation & \multicolumn{2}{|c|}{2.50959} & \multicolumn{2}{|c|}{2.53110} & \multicolumn{2}{|c|}{1.72669} & \multicolumn{2}{|c|}{2.42761} \\
\hline
\end{tabular}

Source: SPSS data running in 2016

The table shows that the variable X1 (Loyalty) had the percentage of agreement at $46.88 \%$ (agree answers) with totally disagree answers at $1.04 \%$. The variable X2 (Competence) had the highest percentage of agreement, with agree answers at $52.50 \%$ and the lowest totally disagree answers at $0.50 \%$. The third variable, X3 (Working Environment) revealed that the agreement level was at $41.94 \%$ and disagreement level at $2.50 \%$. The variable Y (Staff Performance) indicated the percentage of agreement was 50.17\% with disagreement percentage $1.17 \%$.

\section{Classical Assumption Test}

a. Normality Test

\section{Normal P.P Plot of Regression Standardized Residual}

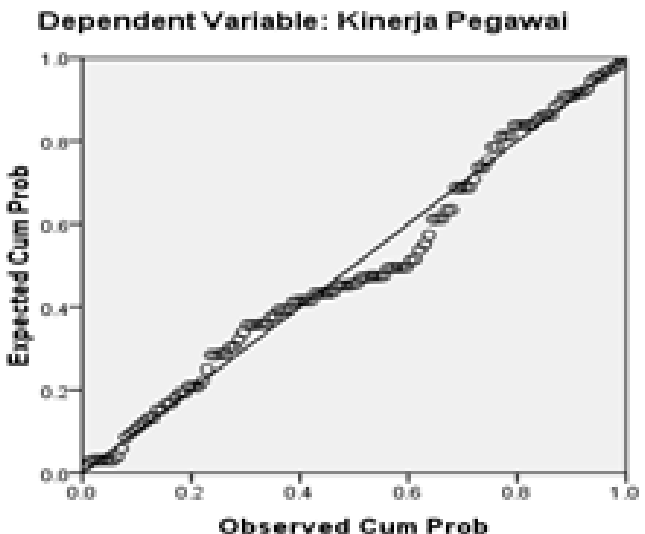


The Influence of Loyalty, Competence, and Working Environment on the Administrative Staff ..

Normality test can be seen at Normal P-P plot beside. Normality assumption shows that residual regression model was normally distributed. As can be seen in the Normal P-P Plot approach through the dots in the picture beside.

The scattered dots show that those dots spread closely to the diagonal line, it means residual was normally distributed.

\section{b. Multicollinearity test}

\begin{tabular}{|l|l|l|l|}
\hline \multicolumn{2}{|l|}{ Model } & Collinearity Statistics \\
\cline { 3 - 4 } \multicolumn{2}{|l|}{1} & Tolerance & VIF \\
\cline { 2 - 4 } & Loyalty & & \\
\cline { 2 - 4 } & Competence & .595 & 1.680 \\
\cline { 2 - 4 } & Working Environment & .541 & 1.849 \\
\hline \multicolumn{2}{|l|}{ a. Dependent Variable: Staff Performance } & 1.279 \\
\hline
\end{tabular}

As shown at the table above, the multicollinearity test had the VIF values for the variable loyalty, competence, and working environment were 1.680, 1.849, and 1.279 consecutively. The tolerance for each variable was $0.595,0.541$ and 0.782 with $\mathrm{VIF}<10$. It can be concluded that there was no multicollinearity on the three dependent variables

\section{c. Autocorrelation test}

\section{Model Summary}

\begin{tabular}{|l|l|}
\hline Model & Durbin-Watson \\
\hline 1 & 2.230 \\
\hline
\end{tabular}

a. Predictors: (Constant), Loyalty, Competence, Working Environment Dependent Variable: Staff Performance

The autocorrelation test shows that there was no autocorrelation on regression model, as the value of

Durbin-Watson (DW) result was 2.230, indicates that this score in between du (1.760) and du (2.481).

\section{d. Heteroskidastity test}

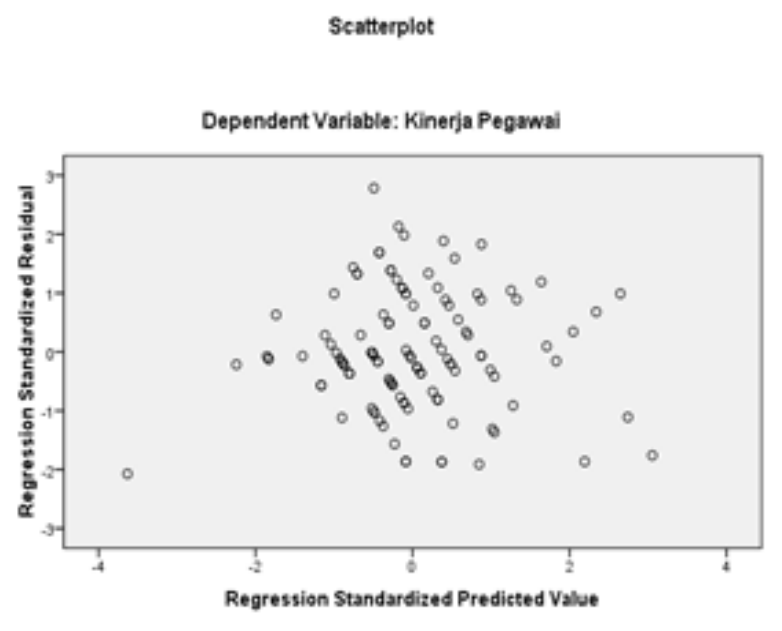

As can be seen from the figure besides, the heteroskidastity test shows that the scatterplot between residual and prediction value from standardisation variables did not create a pattern or certain plot. Therefore, it can be concluded that there was no heteroskedastic, in other word there was a homoskidastity. The classic assumption was fulfilled as the result proved no heteroskedastic in this model.

4. The Results of Linear Multiple Regression Analysis The table below shows the results of linear multiple regression.

Table 1 Coefficients

\begin{tabular}{|c|c|c|c|c|c|c|}
\hline \multirow{2}{*}{\multicolumn{2}{|c|}{ Model }} & \multicolumn{2}{|c|}{ Unstandardized Coefficients } & \multirow{2}{*}{$\begin{array}{l}\text { Standardized Coefficients } \\
\text { Beta }\end{array}$} & \multirow[t]{2}{*}{$\mathrm{t}$} & \multirow[t]{2}{*}{ Sig. } \\
\hline & & $\mathrm{B}$ & Std. Error & & & \\
\hline \multirow[t]{4}{*}{1} & (Constant) & .938 & .784 & & 1.197 & .234 \\
\hline & Loyalty & .370 & .050 & .382 & 7.419 & .000 \\
\hline & Competence & .313 & .052 & .327 & 6.042 & .000 \\
\hline & $\begin{array}{l}\text { Working } \\
\text { Environment }\end{array}$ & .579 & .063 & .412 & 9.162 & .000 \\
\hline \multicolumn{4}{|c|}{ a. Dependent Variable: Staff Performance } & & & \\
\hline
\end{tabular}


The Influence of Loyalty, Competence, and Working Environment on the Administrative Staff..

The results of the table above create the following equal regression:

$$
\mathrm{Y}=0,938+0,370 \times 1+0,313 \times 2+0,579 \times 3+e
$$

The equal regression shows that the analysed independent variables (Loyalty/X1; Competence/X2 and Working Environment/X3) contributed positive influence to dependent variables (Staff Performance/Y). The model of this equal regression can be explained as follows:

- Constant value of 0.938 shows that if the loyalty, competence and working environment variables was assumed as constant or unchanged, so the performance of administrative staff at Manado State University was also 0.938 .

- Loyalty (X1) has regression coefficient at 0.370 , it means every increase point in loyalty variable at one unit will improve the performance of administrative staff at Manado State University at value 0.370, with assumption that other variables are dependent. The positive sign shows that there is one direction relationship between loyalty and administrative staff performance at Manado State University.

- Competence (X2) has regression coefficient at 0.313 , it means every increase point in competence variable at one unit will improve the performance of administrative staff at Manado State University at value 0.313 , with assumption that other variables are dependent. The positive sign shows that there is one direction relationship between competence and administrative staff performance at Manado State University.

- Working Environment (X3) has regression coefficient 0.579, it means every increase point in working environment variable at one unit will improve the performance of administrative staff at Manado State University at value 0.313 , with assumption that other variables are dependent. The positive sign shows that there is one direction relationship between working environment and administrative staff performance at Manado State University.

\section{Hypothesis Test}

Partial Test (t-test)

The t-test results are presented in Table 1. It shows that:

- The results of $t$-test were $t_{\text {count }} 7.419>t_{\text {table }} 1.980$, therefore Ho was rejected and H1 was accepted, it indicates that there was influence between loyalty and staff performance. The loyalty influence to administrative staff performance at Manado State University was 0.382 or $38.2 \%$ (standardised coefficients) at significant level $0.000<0.05$, so the result was significant.

- The results of t-test were $t_{\text {count }} 6.042>t_{\text {table }} 1.980$, therefore Ho was rejected and H1 was accepted, it indicates that there was influence between competence and staff performance. The competence influence to administrative staff performance at Manado State University was 0.327 or $32.7 \%$ (standardised coefficients) at significant level $0.000<0.05$, so the result was significant.

- The results of t-test were $t_{\text {count }} 9.162>t_{\text {table }} 1.980$, therefore Ho was rejected and H1 was accepted, it indicates that there was influence between working environment and staff performance. The working environment influence to administrative staff performance at Manado State University was 0.412 or $41.2 \%$ (standardised coefficients) at significant level $0.000<0.05$, so the result was significant.

\section{Simultaneous Test (F-test)}

F-test was conducted to identify the influence simultaneously between independent variables and dependent variables. The F-test is presented on the table 2, below:

Table 2. ANOVA

\begin{tabular}{|l|l|l|l|l|l|l|}
\hline \multicolumn{2}{|l|}{ Model } & Sum of Squares & df & Mean Square & F & Sig. \\
\hline \multirow{3}{*}{1} & Regression & 572.756 & 3 & 190.919 & 172.287 & $.000^{\mathrm{a}}$ \\
\cline { 2 - 7 } & Residual & 128.544 & 116 & 1.108 & & \\
\cline { 2 - 7 } & Total & 701.300 & & & \\
\hline
\end{tabular}

Table 2 shows that:

The value of $F_{\text {count }}(172.287)>F_{\text {table }}(2.44)$ and research significant value $(0.000)<$ significant value level $(0.05)$. It indicates that alternative hypothesis $(\mathrm{Ha} / \mathrm{H} 1)$ was accepted and Ho was rejected. It can be concluded that the estimated regression model was appropriate, therefore the loyalty, competence and working environment variables simultaneously influence to administrative staff performance at Manado State University.

\section{Determination Coefficient}

Simultaneously

Determination coefficient in this research was purposed to clarify the influence of independent variables (loyalty, competence and working environment) to dependent variable (staff performance) simultaneously. 
The Influence of Loyalty, Competence, and Working Environment on the Administrative Staff ..

Table 3 Model Summary is presented to find out the contribution simultaneously based on the value of Adjusted R Square.

Table 3 Model Summary

\begin{tabular}{|l|l|l|l|}
\hline Model & $\mathrm{R}$ & $\mathrm{R}$ Square & Adjusted R Square \\
\hline 1 & $.904^{\mathrm{a}}$ & .817 & .812 \\
\hline a. & Predictors: (Constant), Loyalty, Competence, Working Environment \\
b. Dependent Variable: Staff Performance & \\
\hline
\end{tabular}

Table 3 Model Summary shows that the value of Adjusted R-Square was 0.812. It indicates that the influence proportion of loyalty, competence and working environment variables to staff performance was $81.2 \%$. It means that loyalty, competence and working environment contributed simultaneously to staff performance at $81.2 \%$. The remains $18.8 \%(100 \%-81.2 \%)$ was influenced by other variables that not included in this linear multiple regression.

\section{Partially}

The contribution of independent variables in partial was obtained from partial correlation quadrat as shown in the table below.

Table 4 Coefficients

\begin{tabular}{|c|c|c|c|c|}
\hline \multicolumn{2}{|c|}{ Model } & \multicolumn{3}{|l|}{ Correlations } \\
\hline & & Zero-order & Partial & Part \\
\hline \multirow[t]{4}{*}{1} & (Constant) & & & \\
\hline & Loyalty & .737 & .567 & .295 \\
\hline & Competence & .756 & .489 & .240 \\
\hline & Working Environment & .699 & .648 & .364 \\
\hline
\end{tabular}

Based on SPSS results it shows that:

- The value of coefficients correlations partial of loyalty, competence and working environment were 0.567; 0.489 ; and 0.648 consecutively. It indicates that the contribution value of loyalty, competence and working environment to administrative staff performance at Manado State University were $32.1 \%\left((0.567)^{2}=0.321\right)$; $23.9 \%\left((0.489)^{2}=0.239\right)$; and $41.9 \%\left((0.648)^{2}=0.419\right)$.

- The total partial contribution of each independent variable to dependent variable was $0.321+0.239+0.419$ $=0.9805$ or $98.05 \%$.

\section{The influence of loyalty to staff performance}

\section{Discussion}

The test results of loyalty had influence to administrative staff performance at Manado State University, it proved that there was a significant influence and positive contribution with beta value of partial correlation coefficient 0.567 . It indicates that loyalty contribution to administrative staff performance at Manado State University was $32.1 \%(0.567)^{2}$. This describes that obedience, responsibility, dedication, and honesty which created from loyalty are able to improve work quality, accuracy, initiative, ability, and communication to the performance of administrative staff at Manado State University. This accordance with Saydam (2000) who claims that loyalty contributes the positive result to performance and can be seen from the prime work of the staff. Ardana (2012) confirms that the employees who have high loyalty are the most likely to work well sustainably. In addition Sonia (2014) states that loyalty influences performance significantly and positively.

\section{The influence of competence to staff performance}

The test results of competence had influence to administrative staff at Manado State University. It proved that there was a significant influence and positive contribution with beta value of partial correlation coefficient 0.489. It indicates that competence contribution to administrative staff performance at Manado State University was $23.9 \%(0.489)^{2}$. It is accepted that knowledge, skills, self-concept and values, selfcharacteristics, and motives which created from competence can increase work quality, accuracy, initiative, ability and communication to the performance of administrative staff at Manado State University. This is closely related to the views of Spencer and Spencer (1993) and Palan (2007) who state that knowledge, expertise, selfconcept and values, self-characteristic, and motives can improve prime performance in working place. Dharma in Arcynthia (2013) confirms that competence contains motivation or trait which cause the results of staff performance. Competence also has positive and significant influence to staff performance. The more competent the staff the higher their performance in company. 
The Influence of Loyalty, Competence, and Working Environment on the Administrative Staff..

\section{The influence of working place to staff performance}

The test results of working place had influence to administrative staff at Manado State University. It proved that there was a significant influence and positive contribution with beta value of partial correlation coefficient 0.648 . It indicates that working place contribution to administrative staff performance at Manado State University was $41.9 \%(0.648)^{2}$. It is accepted that work facilities, salary and allowance, and work relation which created from working place can improve the work quality, accuracy, initiative, ability, and communication to the performance of administrative staff at Manado State University. This result related to the study of Rahmawati (2014) who confirms that working place has positive and significant influence to staff performance. The more appropriate the working place, the higher the performance of the employees. In addition, Spencer (1993) asserts that work relation is an effort to connect and develop the social relation in order to keep warm and close, share information to create support and empathy from colleague.

\section{The influence of loyalty, competence, and working environment to staff performance}

The test results proved that loyalty, competence, and working environment had significant influence and positive contribution to staff performance. It proved with the value of Adjusted R-Square, 0.812. It indicates that loyalty, competence and working environment simultaneously contributed to administrative staff performance at Manado State University. This is related to the study of Untari (2014) in CV. Buana Mas Jaya in Surabaya asserts that competence and working environment contribute significant influence to staff performance simultaneously. The study of Suryandita and Netra (2016) that to the staff of Water Utilities Company (PDAM) in Tabanan Regency, also concluded that organisational culture, competence and physical working environment give significant and positive influence to staff performance simultaneously. In related work, the study of Dermawan (2012) in Public Work Service (Dinas PU), Tabanan Regency affirms that motivation, working environment, competence, and compensation are simultaneously influence staff performance and job satisfaction. Another study of Isnain (2012) in Education, Youth and Sport Agency in Tojo Unauna Regency also confirms that competence, working environment and organisation commitment are simultaneously influence staff performance.

\section{Conclusions and Recommendations}

Based on the analysis results and discussion the conclusions of this study are presented below.

1. Loyalty is closely related, influentially and positively contributed to administrative staff performance at Manado State University. The indicators of loyalty such as: obedience, responsibility, dedication, and honesty can clarify the indicators of staff performance about work quality, accuracy, initiative, ability and communication.

2. Competence is closely related, influentially and positively contributed to administrative staff performance at Manado State University. The indicators of competence such as: knowledge, skills, self-concept and values, self-characteristic, and motives can clarify the indicators of staff performance about work quality, accuracy initiative, ability and communication.

3. Working environment is closely related, influentially and positively contributed to administrative staff performance at Manado State University. The indicators of working environment such as: work facilities, salary and allowance, and work relation can clarify the indicators of staff performance about work quality, accuracy, initiative, ability and communication.

4. Loyalty, competence, and working environment have relationship, influence and positive contribution to administrative staff performance at Manado State University.

Based on the results and discussions, several recommendations that can be drawn are as follows:

a. The results of this research are expected to give the idea contribution to the staff at Manado State University in order to have concern on research variables, so the performance and administration service could be improved. Moreover, this study could be the reference for bachelor degree or postgraduate students who are interested in this topic of research.

b. Research sample in this study is still limited with only multiple regression analysis technique, therefore it will be the opportunity for further studies to conduct this kind of research and use the various sample and comprehensive analysis technique.

\section{References}

[1]. Arcynthia M., Lian. 2013. Analysis of Effect of Competence on Employee Performance at PT. Bank Bukopin, Tbk Branch Makassar. Faculty of Economics and Business, University of Hasanuddin Makassar.

[2]. Ardana, I Komang. 2012. Human Resource Management. Yogyakarta: Graha Ilmu

[3]. As'ad, Mohammad. 2001. Psychology of Industrial. Liberty: Yogyakarta

[4]. Basuki and Susilowati (2005). Impact Leadership and Work Environment Spirit Work. Journal JRBI, Vol.1, No.1, Jan. 2005

[5]. Dhermawan, AANB, (2012). Effect of Motivation and Environmental Working, Competence, Compensation on Job Satisfaction and Employee Performance at Environmental Office of Public Works Province of Bali. Journal of Management, Business Strategy and Entrepreneurship, Vol.6 No.2. 
The Influence of Loyalty, Competence, and Working Environment on the Administrative Staff ..

[6]. G. Tyssen, Theodore, 2003. Business and Management Handbook for Beginners Managers, Translator: Hadyana, Print 1, Jakarta. Publisher: Arcan

[7]. Gibson, Ivancevich Donnelly. 1996. Organizational Behaviour: Process Structure. Translators: Nunuk Adiarni. Binarupa Aksara. Jakarta.

[8]. Hasibuan, P.S. Malayu. 2013. Human Resources Management. Publisher: PT. Bumi Aksara, Jakarta.

[9]. Isnain, M, 2012. Effect of Competence, Work Environment, and Organizational Commitment on Employee Performance Department of Education Youth and Sports, Tojo Unauna Regency. E-Journal Katalogis, Vol 1 No 1, December 2012 pp 104-113. ISSN: 2302-2019

[10]. Mangkunegara, A.P, 2005. HR Performance Evaluation. Bandung: PT. Refika Aditama

[11]. Mathis,R.L and Jackson, J.H, 2006. Human Resource Management. Ed 10. Salemba Empat. Jakarta.

[12]. Palan, R. 2007. Competency Management. Implementing of Technique Competency-based HR Management to Enhance Competitiveness Organization. Translators: Octa Melia Jalal. Publisher: PPM Jakarta

[13]. Rahmawati, Nela R. dkk. 2014. Effect of Work Environment on Employee Performance (Study on Employee Tax Office Primary North Malang. Journal of Business Administration (JAB) Vol. 8 No. March 2, 2014. Malang: UB's Faculty of Business Administration.

[14]. Sari, Emilia Noviani Asta. 2009. Effect of Work Environment on Employee Performance Production Department PT. Glory Industrial Semarang II. Semarang. Semarang State University.

[15]. Saydam, Gouzali. 2000. Human Resource Management: "A micro approach in the question and answer". Jakarta: Djambatan

[16]. Sedarmayanti, 2007. Human Resource Management, Reforms and Management Government employees. PT. Refika Aditama. Bandung

[17]. Simamora, Henry, 1997. Human Resource Management. Yogyakarta: STIE YKPN

[18]. Sonia, I.P, 2014. "Influence of Leadership Style and Employee Loyalty on Employee Performance PT. Alam Perista Kudus" Diponegoro University of Semarang

[19]. Spencer, Lyle M. and Signe M. Spencer. 1993. Competence Work: Model for Superior Performance. Canada: John Wiley and Sons. Inc

[20]. Sugiyono, 2007. Statistics for Research. Alfabeta. Bandung

[21]. Suryandita, I.M.A and Netra, I.G.S, 2016. Influence of Organizational Culture, Competence, Physical Work Environment and Employee Service Performance PDAM In Tabanan district. E-Journal of Management UNUD, Vol 5, No 4, 2016:2054-2079. ISSN: 2302-8912

[22]. Untari, S, 2014. Influence of Competency and Work Environment on Employee Performance. Journal of Management Studies and Research, Vol 3 No 10 